\title{
Modifikasi Pembagi Daya Wilkinson Dual Band pada Frekuensi L-Band dan S-Band
}

\author{
Fithqoti Afiroh Zuqri ${ }^{1}$, Bambang Setia Nugroho ${ }^{2}$, Budi Syihabuddin ${ }^{3}$ \\ ${ }^{1,2,3}$ Program Studi S1 Teknik Telekomunikasi, Fakultas Teknik Elektro, Universitas Telkom \\ ${ }^{1,2,3} \mathrm{Jl}$. Telekomunikasi no. 1, Dayeuh Kolot, Bandung, 40257 \\ Email korespondensi :budisyihab@telkomuniversity.ac.id
}

Dikirim 30 Maret 2016, Diperbaiki 26 April 2016, Diterima 28 April 2016

\begin{abstract}
Abstrak - Pembagi daya Wilkinson merupakan pembagi daya yang menggunakan saluran dengan panjang $\lambda / 4$ dan menyisipkan komponen isolasi antar kedua port keluaran. Dengan menggunakan panjang saluran $\lambda / 4$, bandwidth yang dihasilkan relatif sempit karena berhubungan dengan panjang saluran yang tetap. Penelitian ini melakukan modifikasi dari penelitian sebelumnya yang dapat menghasilkan pembagi daya Wilkinson yang bersifat dual band menjadi wide band dengan area kerja dari rentang L-Band hingga S-Band. Dari simulasi didapatkan bandwidth dari nilai returnloss dibawah $-10 \mathrm{~dB}$ sebesar $3.6355 \mathrm{GHz}$, dan nilai isolasi antara port 2 dan port 3, pada frekuensi $1,27 \mathrm{GHz}$ dan 2,3 GHz, nilai isolasi parameter S23 dan S32 dengan komponen isolasi resistor $100 \mathrm{ohm}$ bernilai $-9,7521 \mathrm{~dB}$ dan $-12,3626 \mathrm{~dB}$.
\end{abstract}

Kata kunci - Pembagi Daya Wilkinson, Dual Band, L-Band, S-Band, Mikrostrip.

Abstract - Wilkinson power divider is a power divider that uses $\lambda / 4$ transmission lines and insert isolation component between the two output ports. Using $\lambda / 4$ transmission lines, which is the bandwidth of it will be narrow because the transmission lines length is fixed. This research modified previous work that can produce a dual band Wilkinson power divider into a wide band Wilkinson power divider that will work at L-Band and SBand. From the simulation result, bandwidth $\mathrm{S} 11$ below $-10 \mathrm{~dB}$ is $3.6355 \mathrm{GHz}$ and isolation between port 2 and port 3, at frequency $1.27 \mathrm{GHz}$ and $2.3 \mathrm{GHz}$, the $\mathrm{S} 23$ and S32 with a $100 \mathrm{ohm}$ resistor as a isolation component are $-9.7521 \mathrm{~dB}$ and $-12.3626 \mathrm{~dB}$.

Keywords - Wilkinson Power Divider, Dual Band, L-Band, S-Band, Microstrip.

\section{PENDAHULUAN}

Power Divider merupakan salah satu komponen gelombang mikro pasif yang dapat berfungsi sebagi pembagi daya maupun sebagai penggabung daya [1]. Pembagi daya dapat berupa 4 port seperti bidirectional coupler ataupun 3 port seperti T-Juction dan pembagi daya Wilkinson (Wilkinson Power Divider). Pada penelitian [2] dihasilkan pembagi daya dengan kemampuan melewatkan 2 frekuensi yang berbeda. Pembagi daya tersebut bekerja pada frekuensi $1 \mathrm{GHz}$ dan $1,8 \mathrm{GHz}$ serta $1 \mathrm{GHz}$ dan 4 GHz.

Penelitian tentang pembagi daya dual band juga dilakukan oleh [3] yang menganalisis kinerja dari pembagi daya frekuensi $1,1 \mathrm{GHz}$ dan 2,2 GHz. Selain itu, ada juga penelitian [4] yang menganalisis pengaruh dari komponen isolasi terhadap bandwidth isolasi dari pembagi daya Wilkinson. Serta pada penelitian [5] mengajukan model pembagi daya yang mempunyai respon frekuensi tri-band dengan memanfaatkan komponen induktor.
Mengacu pada penelitian [2], pada penelitian ini dirancang dan dimodifikasi bentuk pembagi daya Wilkinson dual band yang dapat bekerja pada frekuensi $1,27 \mathrm{GHz}$ dan 2,3 $\mathrm{GHz}$ untuk digunakan pada lisensi frekuensi radio amatir [6]. Dengan menggunakan pembagi daya Wilkinson diharapkan dapat memberikan tingkat isolasi antar port output tinggi karena adanya penambahan resistor untuk mengatur daya yang keluar di port output [1].

Dari peraturan radio amatir [6] pada spektrum LBand untuk keperluan amatir dapat digunakan frekuensi $1260 \mathrm{MHz}$ - $1300 \mathrm{MHz}$, serta pada spektrum S-Band dapat digunakan frekuensi 2300 $\mathrm{MHz}$ - $2450 \mathrm{MHz}$. pemilihan frekuensi tersebut didasari oleh perkembangan penginderaan jauh menggunakan gelombang mikro yang telah dikembangkan oleh [7] dengan menggunakan pesawat tanpa awak dan [8] dengan menggunakan satelitmikro.

Penelitian pembagi daya dual band dimaksudkan sebagai sistem Software Defined Radio yang diimplementasikan pada teknologi penginderaan jauh 
berbasis gelombang mikro dengan menggunakan perangkat radio front end yang sama, yang hanya perlu dilakukan penyesuaian pada bagian base band. Sehingga untuk mendapatkan karakteristik objek yang berbeda dan lebar pita yang berbeda untuk kebutuhan yang berbeda, dapat disesuaikan dengan pita yang tersedia, baik pada L-Band atau S-Band.

Artikel ini terdiri dari 4 bagian dengan bagian pertama berisi tentang pendahuluan. Kemudian bagian kedua tentang metodologi penelitian yang berisi teori pendukung dari pembagi daya Wilkinson serta desain pembagi daya Wilkinson, khususnya yang bersifat dual band. Pada bagian ketiga berisi analisis dari perancangan, dan pada bagian terakhir berisi tentang kesimpulan dan saran dari penelitian ini.

\section{METODOLOGI PENELITIAN}

Penelitian ini dilakukan dengan cara merancang sesuai dengan penelitian [2], kemudian dilakukan optimasi untuk mendapatkan frekuensi L-Band dan SBand sesuai dengan ketentuan pada [6]. Setelah dilakukan optimasi untuk mendapatkan frekuensi yang diinginkan, dilakukan modifikasi dari penelitian [2], dengan cara menghilangkan komponen induktor dan kapasitor sehingga hanya tersisa resistor sebagaimana teori pembagi daya Wilkinson pada [1]. Setelah itu, dilakukan analisis dari hasil perancangan, optimasi serta modifikasi untuk mengetahui kinerja dari perancangan.

\section{A. Pembagi Daya Wilkinson Power Dual Band}

Wilkinson power divider merupakan jenis rangkaian power divider yang dapat memperoleh isolasi antar port output ketika kondisi sepadan di semua port dipertahankan. Pada pembagi daya Wilkinson, daya yang masuk akan dibagi menjadi $N$ way pada masing-masing output, dan memiliki isolasi antar port output untuk mencegah daya berpindah di antara kedua port output [1]. Gambar pembagi daya dalam bentuk mikrostrip dan bentuk rangkaian pengganti ditunjukkan oleh Gambar 1 (a) dan (b). Pada Gambar 1, terdapat dua nilai impedansi yang digunakan, yaitu impedansi $Z_{0}$ dan impedansi $\sqrt{2} Z_{0}$ dengan panjang $\lambda / 4$. Dengan penambahan tersebut, pembagi daya tidak bersifat resiprok dan resistif sehingga antar port tidak bisa digunakan secara berkebalikan. Ketika input digunakan sebagai output, atau sebaliknya, sifat rangkaian 3 port tersebut akan berubah dari pembagi daya menjadi penggabung daya [1].

Untuk mendapatkan respon dual band, model rangkaian pengganti yang dilakukan oleh Lei $\mathrm{Wu}$ dkk pada penelitian [2] dilakukan modifikasi dari [1] berupa penambahan impedansi baru sebesar $Z_{2}$ dan komponen $\mathrm{L}$ dan $\mathrm{C}$ seperti terlihat pada Gambar 2. Analisis rangkaian untuk pembagi daya Wilkinson dual band [2] menggunakan analisis mode genap dan mode ganjil.

\section{1) Analisis Pembagi Daya Wilkinson Mode Genap}

Pada analisis mode genap, memiliki dua sinyal dengan magnitude dan fasa yang sama. Untuk menyelesaikan transformasi pada dua frekuensi yang berbeda $f_{1}$ dan $f_{2}=$ m. $f_{1}$ (dengan asumsi $m$ adalah rasio dari kedua frekuensi) dapat mengikuti penurunan persamaan sebagai berikut [9].

$$
\begin{aligned}
& l_{1}=l_{2}=\frac{n \pi}{\beta_{1}+\beta_{2}} \\
& Z_{2}=Z_{0} \sqrt{\frac{1}{2 a}+\sqrt{\frac{1}{4 a^{2}}+2}}
\end{aligned}
$$

dan

$$
Z_{1}=\frac{2 Z_{0}^{2}}{Z_{2}}
$$

ketika,

$$
\begin{aligned}
& \alpha=\left(\tan \left(\beta_{1} l_{1}\right)\right)^{2} \\
& \beta=\frac{2 \pi}{\lambda}
\end{aligned}
$$

$\mathrm{n}$ merupakan integer positif.

\section{2) Analisis Pembagi Daya Wilkinson untuk Mode Ganjil}

Persamaan impedansi Z' dan $Z_{\text {ganjil }}$ pada frekuensi pertama $\left(f_{1}\right)$ adalah sebagai berikut :

$$
\begin{aligned}
& Z^{\prime} \omega_{1}=Z_{1} \frac{0+j \cdot Z_{1} \cdot \tan \left(\beta_{1} l_{1}\right)}{Z_{1}+j \cdot 0 \cdot \tan \left(\beta_{1} l_{1}\right)} \\
& Z_{\text {ganjil }}^{\prime} \omega_{2}=Z_{1} \frac{Z^{\prime} \omega_{1}+j \cdot Z_{2} \cdot \tan \left(\beta_{1} l_{2}\right)}{Z_{2}+j \cdot Z^{\prime} \omega_{1} \cdot \tan \left(\beta_{1} l_{2}\right)}
\end{aligned}
$$

Menggunakan persamaan (6) substitusi dengan (7) dan $l_{1}=l_{2}$ dari persamaan (1) menjadi

$$
\begin{aligned}
Z_{\text {ganjil }}^{\prime} \omega_{1} & =Z_{2} \frac{j \cdot Z_{1} \cdot \tan \left(\beta_{1} l_{1}\right)+j \cdot Z_{2} \cdot \tan \left(\beta_{1} l_{1}\right)}{Z_{2}+j \cdot j \cdot Z_{1} \cdot\left(\tan \left(\beta_{1} l_{1}\right)\right)^{2}} \\
& =Z_{2} \frac{j \cdot\left(Z_{1}+Z_{2}\right) \cdot \tan \left(\beta_{1} l_{1}\right)}{Z_{2}-Z_{1} \cdot\left(\tan \left(\beta_{1} l_{1}\right)\right)^{2}}
\end{aligned}
$$

Port 2 paralel dengan $\mathrm{R} / 2, \mathrm{~L} / 2$, dan $2 \mathrm{C}$, impedansi output Z" odd pada port 2 menjadi

$$
Z^{\prime \prime}{ }_{\text {ganjil }}, \omega_{1}=\frac{1}{\left(\frac{1}{Z_{\text {ganjil }}^{\prime} \omega_{1}}+\frac{2}{R}+j \cdot \omega_{1} \cdot 2 C-\frac{2}{\omega_{1} L}\right)}
$$

Untuk matching impedansi ke $\mathrm{Z}_{0}$ pada port 2, $Z_{\text {ganjil }}, \omega_{1}$ harus sama dengan $Z_{0}$, maka

$R=2 . Z_{0}$

Dan 
$\frac{1}{Z_{\text {ganjil }}^{\prime} \omega_{1}}=j \cdot\left(\frac{2}{\omega_{1} L}-2 \omega_{1} C\right)$

Dengan persamaan (8), (11), maka dapat dituliskan

$\frac{Z_{2}-Z_{1} \cdot \tan ^{2}\left(\beta_{1} l_{1}\right)}{Z_{2}\left(Z_{1}+Z_{2}\right) \cdot \tan \left(\beta_{1} l_{1}\right)}=\omega_{1} \cdot 2 C-\frac{2}{\omega_{1} L}$

Ulangi persamaan di atas untuk frekuensi kedua $\left(\mathrm{f}_{2}\right)$, maka akan menjadi persamaan:

$$
\frac{Z_{2}-Z_{1} \cdot \tan ^{2}\left(\beta_{2} l_{1}\right)}{Z_{2}\left(Z_{1}+Z_{2}\right) \cdot \tan \left(\beta_{2} l_{1}\right)}=\omega_{2} \cdot 2 C-\frac{2}{\omega_{2} L}
$$

Dari persamaan (12) dan (13) bisa diperoleh C dan L, persamaannya dapat diselesaikan dengan persamaan berikut ini.

$$
\begin{aligned}
& p=\tan \left(\beta_{1} l_{1}\right) \\
& q=\tan \left(\beta_{2} l_{1}\right) \\
& A=\frac{Z_{2}-Z_{1} \cdot p^{2}}{Z_{2} \cdot p \cdot\left(Z_{1}+Z_{2}\right)} \\
& B=\frac{Z_{2}-Z_{1} \cdot \mathrm{q}^{2}}{Z_{2} \cdot \mathrm{q} \cdot\left(Z_{1}+Z_{2}\right)}
\end{aligned}
$$

Persamaan (12) dan (13) akan menjadi

$$
\begin{aligned}
& A=\omega_{1} .2 C-\frac{2}{\omega_{1} \cdot L} \\
& B=\omega_{2} \cdot 2 C-\frac{2}{\omega_{2} \cdot L}
\end{aligned}
$$

Dari persamaan di atas dapat diperoleh nilai $\mathrm{C}$ dan $\mathrm{L}$ dengan persamaan sebagai berikut.

$$
\begin{aligned}
& C= \frac{\frac{B}{\omega_{1}}-\frac{A}{\omega_{2}}}{\frac{2 \omega_{2}}{\omega_{1}}-\frac{2 \omega_{1}}{\omega_{2}}} \\
& L= \frac{2 \omega_{2}}{\omega_{1}}-\frac{2 \omega_{1}}{\omega_{2}} \\
& B \omega_{1}-A \omega_{2}
\end{aligned}
$$

Jadi, persamaan (1) - (5), (10), (20), dan (21) merupakan parameter desain dari pembagi daya Wilkinson dual band, yang bekerja pada dua frekuensi $f_{1}$ dan $f_{2}$. Panjang $l_{1}$ dan $l_{2}$, impedansi karakteristik $Z_{1}$ dan $Z_{2}$ dari saluran transmisi, dan $\mathrm{R}$ memiliki nilai yang positif [2].

Dari keseluruhan persamaan di atas, untuk hubungan antara bilangan bulat positif (n) dan perbandingan frekuensi $(\mathrm{m})$, dapat diringkas sebagai berikut [2].
1) $\mathrm{n}=1$, jika dual band Wilkinson power divider yang beroperasi pada $\mathrm{f}_{1}$ dan $\mathrm{m}_{\mathrm{f}} \mathrm{f}_{1}$ memiliki range 1 $<\mathrm{m}<3$

1) $\mathrm{n} \geq 2$, jika dual band Wilkinson power divider yang beroperasi pada $\mathrm{f}_{1}$ dan m. $_{1}$ memiliki range 4 $(\mathrm{n}-1)-1<\mathrm{m}<4 \mathrm{n}-1$.

2) untuk $\mathrm{m}=4 \mathrm{n}-1$, dual frequency Wilkinson power divider konvensional.

\section{B. Desain Pembagi Daya Wilkinson untuk L-Band dan $S$-Band}

Rangkaian yang diusulkan pada penelitian ini adalah seperti pada Gambar 5, dimana pada rangkaian yang diusulkan sedikit berbeda dengan penelitian [2], yaitu menghilangkan komponen induktor dan kapasitor sehingga hanya resistor yang berfungsi sebagai isolasi. Proses perancangan pembagi daya menggunakan metode konvensional dengan dua impedansi karakteristik yang berbeda pada masingmasing transformator. Pada Gambar 6 merupakan desain dalam bentuk saluran mikrostrip sebagai desain yang akan disimulasikan. Perancangan dengan menggunakan persamaan (1) - (5) dengan menghitung impedansi serta tebal dan panjang saluran yang dibutuhan, namun belum menggunakan komponen isolasi seperti $\mathrm{R}, \mathrm{L}$ dan $\mathrm{C}$. Hasil desain dan optimasi awal dapat dilihat pada Tabel 1 dan Gambar 7.

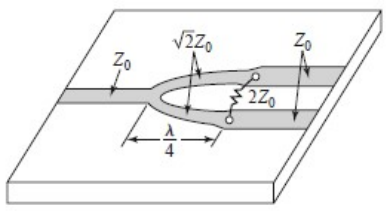

(a)

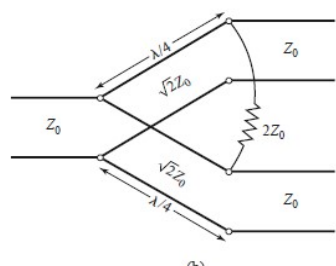

Gambar 1. Pembagi Daya Wilkinson Konvensional (a) Bentuk mikrostrip (b) Rangkaian pengganti [1]

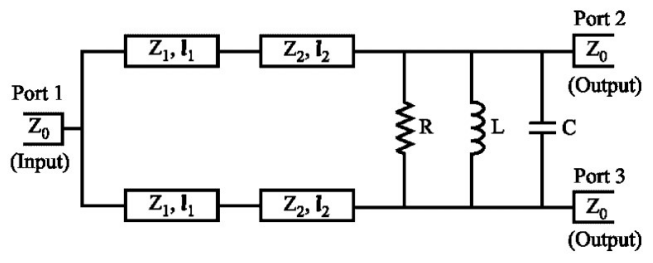

Gambar 2. Pembagi Daya Dual Band [2] 


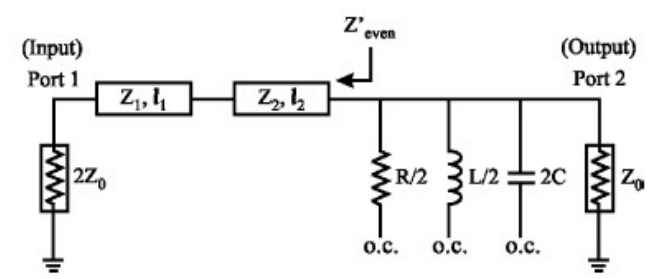

Gambar 3. Rangkaian Pembagi Daya Dengan Analisis Mode Genap [2]

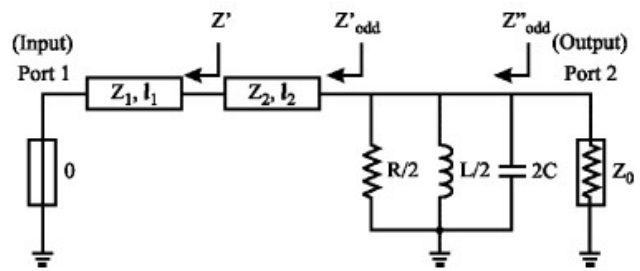

Gambar 4. Rangkaian Pembagi Daya Dengan Analisis Mode Ganjil [2]

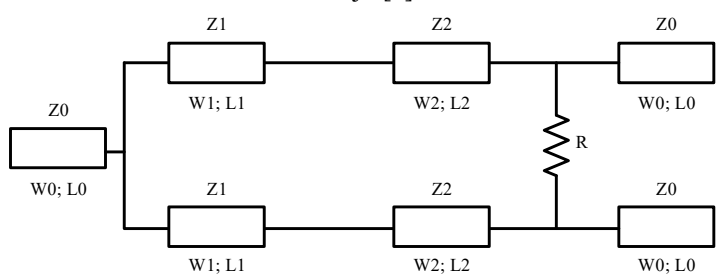

Gambar 5. Rangkaian Dual Band Wilkinson Power Divider Yang Diusulkan

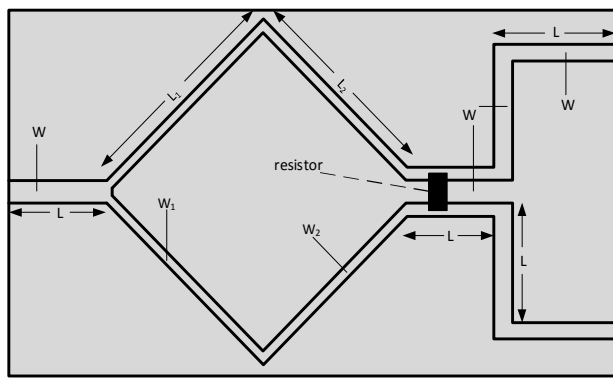

Gambar 6. Desain Dual Band Power Divider

Tabel 1. Dimensi Power Divider

\begin{tabular}{lcc}
\hline \multirow{2}{*}{\multicolumn{1}{c}{ Impedance }} & \multicolumn{2}{c}{ Dimensi } \\
\cline { 2 - 3 } & Perhitungan & Optimasi \\
\hline Impedansi Transformator & $\mathrm{W}_{1}=1,1 \mathrm{~mm}$ & $\mathrm{~W}_{1}=1 \mathrm{~mm}$ dan \\
$\left(\mathrm{Z}_{1}=80,64084536 \Omega\right)$ & dan $\mathrm{L}_{1}=42 \mathrm{~mm}$ & $\mathrm{~L}_{1}=23.1 \mathrm{~mm}$ \\
& & $\mathrm{~W}_{2}=1.9 \mathrm{~mm}$ \\
Impedansi Transformator & $\mathrm{W}_{2}=2 \mathrm{~mm}$ & dan $\mathrm{L}_{2}=23.1$ \\
$\left(\mathrm{Z}_{2}=62,00331827 \Omega\right)$ & dan $\mathrm{L}_{2}=42 \mathrm{~mm}$ & $\mathrm{~mm}$ \\
Impedansi Saluran & $\mathrm{W}=2,9 \mathrm{~mm}$ & $\mathrm{~W}=1 \mathrm{~mm}$ dan \\
Transmisi $\left(\mathrm{Z}_{0}=50 \Omega\right)$ & dan $\mathrm{L}=23 \mathrm{~mm}$ & $\mathrm{~L}=2 \mathrm{~mm}$ \\
\hline
\end{tabular}

\section{HASIL DAN PEMBAHASAN}

Bagian ini membahas tentang hasil optimasi dan pengaruh dari komponen isolasi pada port 2 dan port 3 , yaitu komponen resistor, induktor serta kapasistor.

\section{A. Analisis Hasil Optimasi}

Dari Gambar 7 terlihat hasil yang berbeda antara desain awal yang menggunakan persamaan (1) - (5), dan hasil setelah dilakukan optimasi dengan mengubah panjang serta lebar saluran pada impedansi $Z_{1}$ dan $Z_{2}$. Hasil yang didapatkan dari desain hasil perhitungan dengan memperhatikan nilai S11 terkecil pada suatu frekuensi berada pada frekuensi 0,632 $\mathrm{GHz}$ dan frekuensi $1,18 \mathrm{GHz}$ dengan nilai S11 secara berurutan sebesar $-44,9 \mathrm{~dB}$ dan $-32,73 \mathrm{~dB}$. Sedangkan tegangan dari port 1 ke port 2 dan port 3 pada frekuensi minimum tersebut sebesar $-3,44 \mathrm{~dB}$ dan $3,46 \mathrm{~dB}$ serta $-3,79 \mathrm{~dB}$ dan $-3,87 \mathrm{~dB}$. Dilihat dari nilai S11 yang kurang dari $-10 \mathrm{~dB}$, diperoleh frekuensi minum pada $0,249 \mathrm{GHz}$ sampai dengan $2 \mathrm{GHz}$, lalu respon frekuensi dari grafik S11 turun kembali. Mengacu dari spesifikasi yang menginginkan power divider bekerja pada frekuensi $1,27 \mathrm{GHz}$ dan $2,3 \mathrm{GHz}$ maka hasil perancangan ini harus dilakukan optimasi. Namun, jika dibatasi menjadi sebuah bandwidth dengan batasan $\mathrm{S} 11$ sebesar $-10 \mathrm{~dB}$, maka bandwidth hasil perancangan sebesar $1,751 \mathrm{GHz}$.

Sedangkan hasil dari optimasi, untuk nilai S11 di bawah $-10 \mathrm{~dB}$ mulai dari frekuensi $0,234 \mathrm{GHz}$ sampai dengan $4 \mathrm{GHz}$ sehingga bandwidth yang diperoleh dari nilai S11 sebesar 3,766 GHz. Jadi dilihat dari respon S11 tersebut, dengan dilakukan optimasi power divider tersebut dapat berkerja pada frekuensi yang diinginkan, yaitu pada frekuensi $1,27 \mathrm{GHz}$ dan 2,3 GHz. Nilai S21 dan S31 pada frekuensi 1,27 GHz dan $2,3 \mathrm{GHz}$ sebesar $-3,371 \mathrm{~dB}$ dan $-3,371 \mathrm{~dB}$ serta $3,642 \mathrm{~dB}$ dan $-3,532 \mathrm{~dB}$. Walaupun hasil ini tidak memenuhi karakteristik dari parameter S Wilkinson power divider untuk port 1 ke port 2 dan 3 sebesar -3 $\mathrm{dB}$, namun hasil ini lebih baik dari hasil perancangan dengan perhitungan.

Setelah dilakukan perancangan dan optimasi seperti pada Gambar 7, maka dilakukan perbandingan desain yang diusulkan tanpa menggunakan komponen isolasi $\mathrm{L}$ dan $\mathrm{C}$, serta tanpa $\mathrm{R}, \mathrm{L}$ dan $\mathrm{C}$ dan rangkaian dengan $\mathrm{R}$, L dan $\mathrm{C}$ seperti pada Gambar 8 dan Gambar 9. Pada Gambar 8 dan Gambar 9 diambil data 6 data parameter S, dengan nilai S23 sama dengan S32, S31 sama dengan S13 serta S21 sama dengan S12. Pada Gambar 8, bandwidth S11 di bawah -10 dB untuk hasil optimasi dengan menggunakan resistor $100 \mathrm{ohm}$ sesuai dengan persamaan (10) diperoleh sebesar $3.6355 \mathrm{GHz}$, lebih sempit dibandingkan hasil optimasi tanpa menggunakan resistor sebagai komponen isolasi. Namun dibandingkan tanpa menggunakan komponen isolasi, nilai S23 dan S32 lebih kecil dengan menggunakan resistor $100 \mathrm{ohm}$. Dengan menggunakan resistor $100 \mathrm{ohm}$ sebagai isolasi, nilai S23 dan S32 minimum berada pada frekuensi 2,61 $\mathrm{GHz}$ dengan nilai $-16,2322 \mathrm{~dB}$ serta nilai maksimum pada $1,74 \mathrm{GHz}$ dengan nilai $-6,449$ dB. Sedangkan tanpa menggunakan komponen osilasi, nilai S23 dan S32 minimum berada pada 
ISSN : 2085-3688; e-ISSN : 2460-0997

Modifikasi Pembagi Daya Wilkinson Dual Band pada Frekuensi L-Band dan S-Band

frekuensi 2,28 GHz dengan nilai $-8,009 \mathrm{~dB}$. Nilai S23 bernilai sama dengan S32 karena karakteristik Wilkinson yang simetris. Dan nilai S32 dan S23 maksimum berada pada $1,39 \mathrm{GHz}$ dengan nolai $-5,9$ GHz. Pada frekuensi yang $1,27 \mathrm{GHz}$ dan $2,3 \mathrm{GHz}$, nilai isolasi parameter S23 dan S32 tanpa komponen isolasi sebesar $-5,9175 \mathrm{~dB}$ dan $-8,0116 \mathrm{~dB}$ sedangkan dengan komponen isolasi resistor $100 \mathrm{ohm}$ lebih rendah, bernilai $-9,7521 \mathrm{~dB}$ dan $-12,3626 \mathrm{~dB}$.
Pada Gambar 9, dengan menggunakan komponen isolasi secara lengkap yaitu resistor $100 \mathrm{ohm}$, induktor $7,5 \mathrm{nH}$ dan kapasitor $1.2 \mathrm{pF}$ sesuai dengan persamaan (10), (20) dan (21), nilai S23 dan S32 tidak berubah secara signifikan. Nilai minimum sebesar $-15,5188 \mathrm{~dB}$ pada frekuensi $2,4 \mathrm{GHz}$ dan nilai maksimum sebesar $-6,5927 \mathrm{~dB}$ pada frekuensi 1,72 $\mathrm{GHz}$, tidak lebih baik dengan hanya menggunakan isolasi berupa resistor $100 \mathrm{ohm}$. Sedangkan pada frekuensi $1,27 \mathrm{GHz}$ dan 2,3 $\mathrm{GHz}$ nilai S23 dan S32 sebesar $-10,4871 \mathrm{~dB}$ dan $-14,3731 \mathrm{~dB}$.

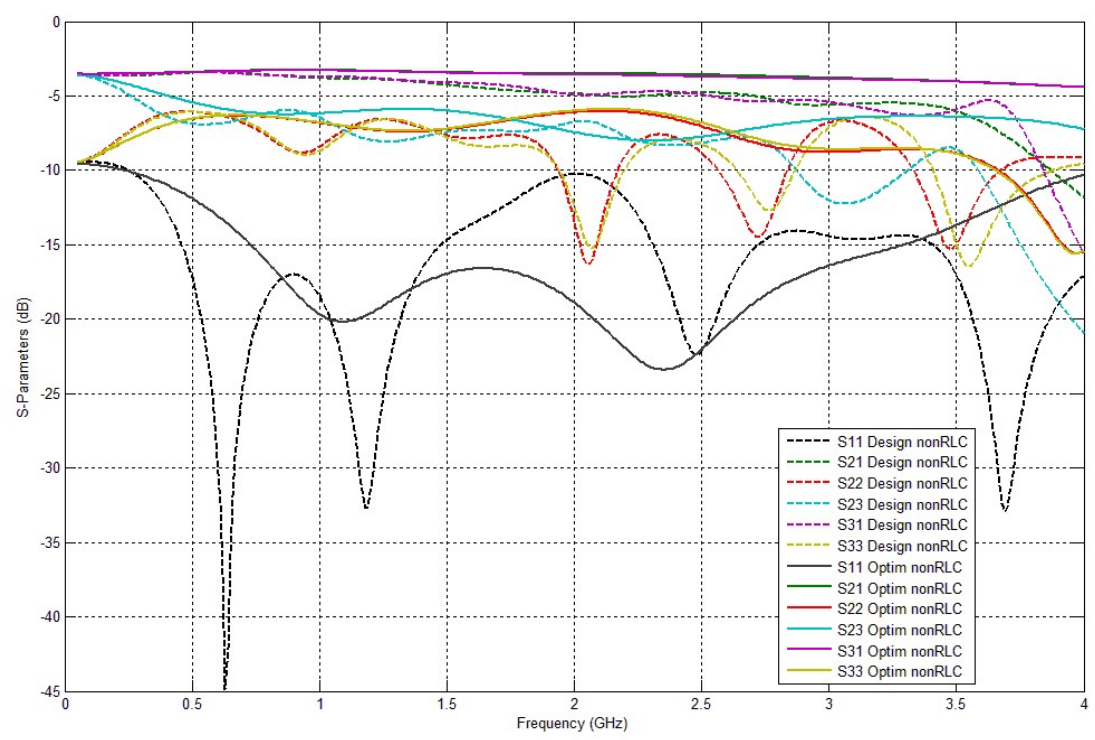

Gambar 7. Hasil simulasi antara Desain dan Optim Tanpa RLC

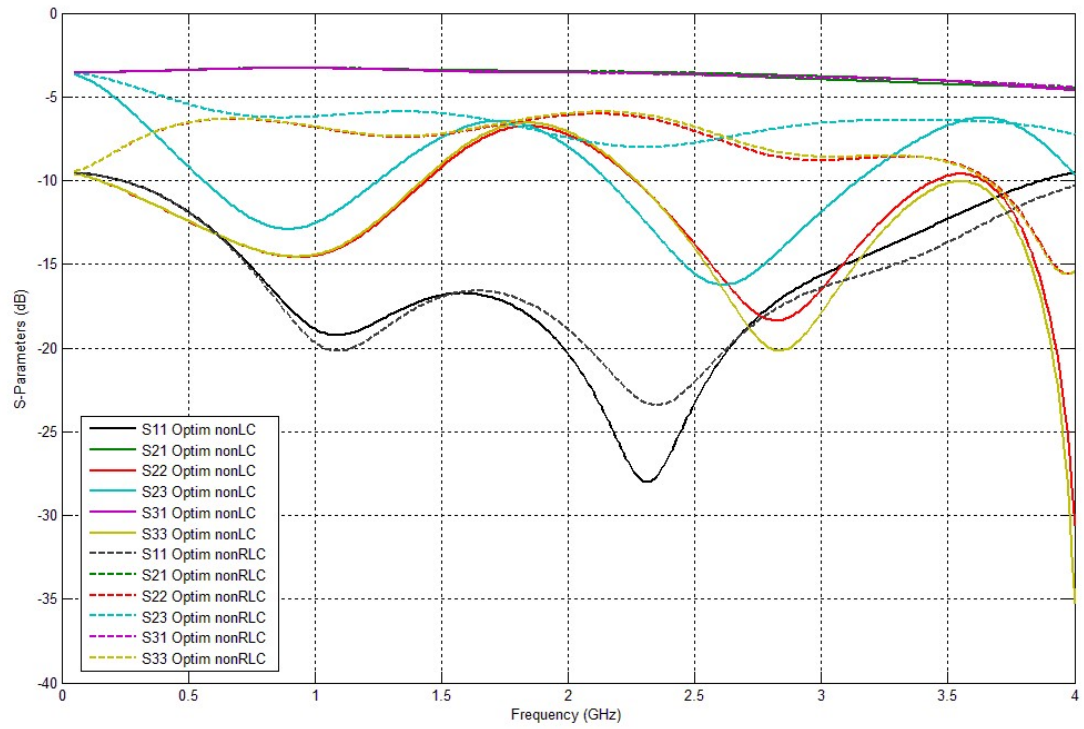

Gambar 8. Hasil simulasi antara Optim tanpa LC dan Optim Tanpa RLC 


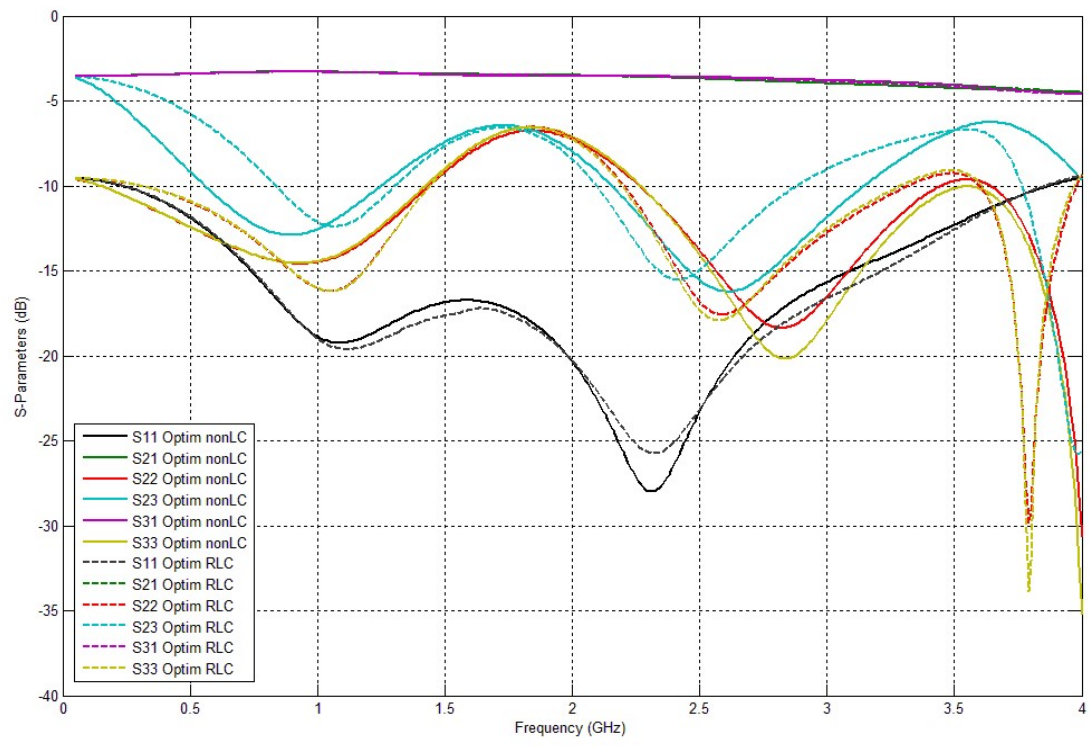

Gambar 9. Hasil simulasi antara Optim tanpa LC dan Optim dengan RLC

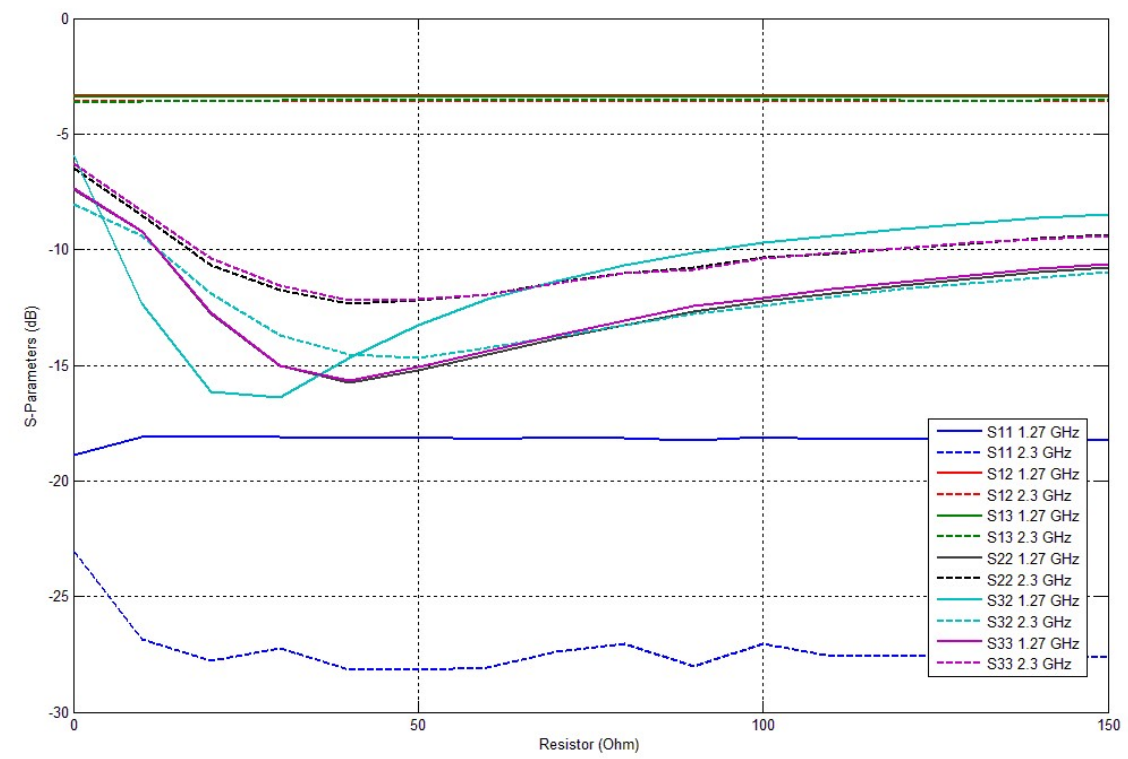

Gambar 10. Pengaruh Nilai Resistansi pada Frekuensi 1,27 GHz dan 2,3 GHz 


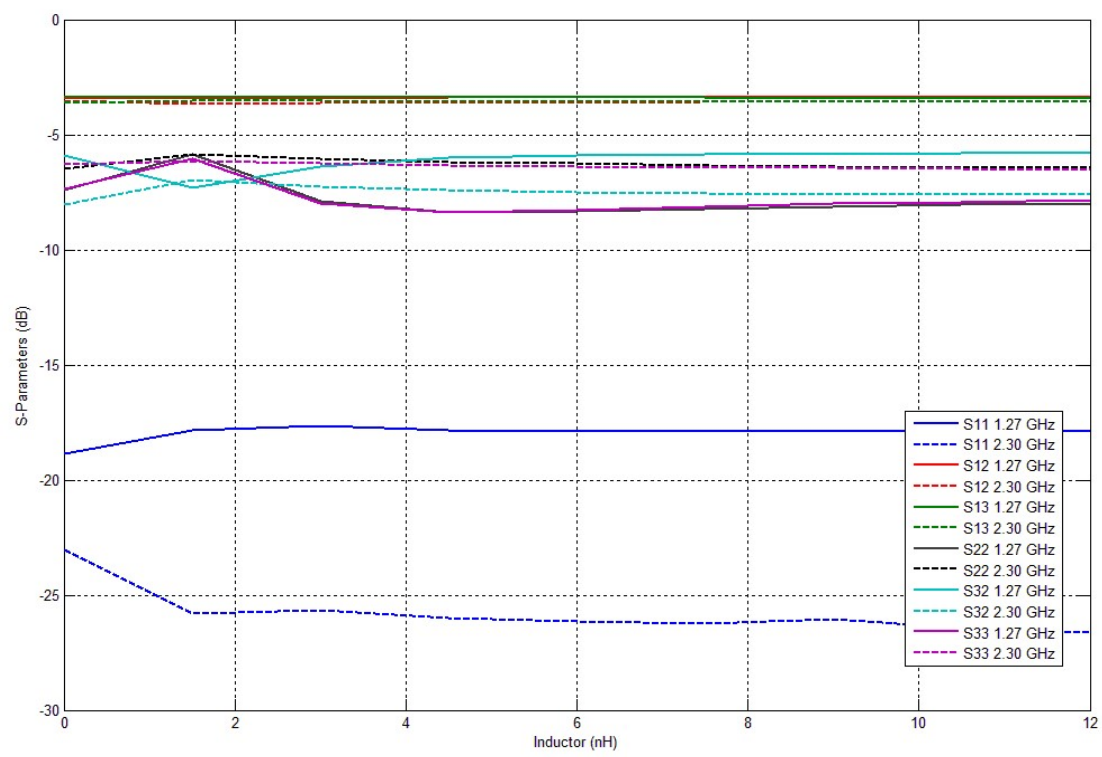

Gambar 11. Pengaruh Nilai Induktasi pada Frekuensi 1,27 GHz dan 2,3 GHz

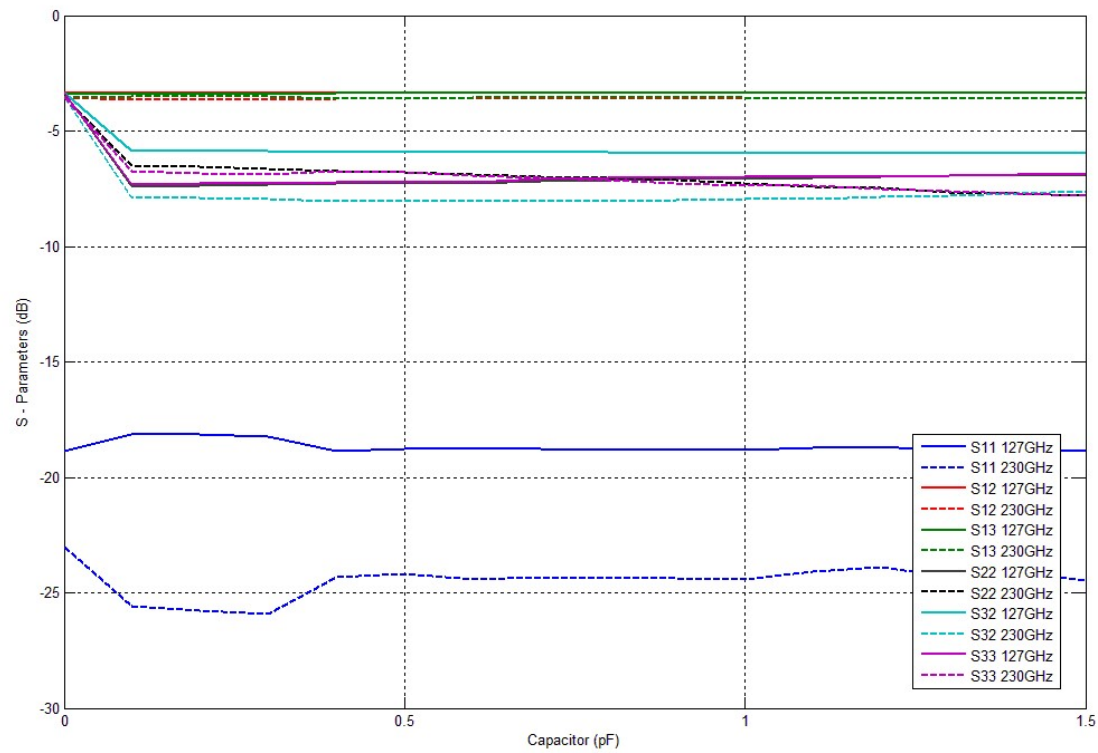

Gambar 12. Pengaruh Nilai Kapasitansi pada Frekuensi 1,27 GHz dan 2,3 GHz.

B. Analisis Pengaruh $R, L$ dan $C$ terhadap Parameter $S$

Gambar 10 dan Gambar 11 merupakan resume dari nilai resistor, induktor, serta kapasitor pada frekuensi 1,27 GHz dan 2,3 GHz yang juga diperlihatkan pada bagian appendix. Gambar 10 memperlihatkan nilai S11 pada frekuensi $1,27 \mathrm{GHz}$ terkecil pada resistor $0 \mathrm{ohm}$, sebesar $-18,872 \mathrm{~dB}$, dan pada frekuensi $2,3 \mathrm{GHz}$ pada resistor $40 \mathrm{ohm}$. Untuk S11, S22, S32 dan S33 diperhatikan nilai terkecil sedangkan untuk nilai S12 dan S13 diperhatikan nilai terbesar. Ini berdasarkan sifat dari parameter S untuk rangkaian 3 port yang bekerja sebagai pembagi daya.

Dari grafik pada Gambar 10, terjadi perubahan nilai signifikan pada S32, S33 dan S22. Ini berarti penambahan resistor mempengaruhi nilai dari impedansi input ketika pada port 2 dan port 3 digunakan sebagai input. Namun penambahan nilai kapasitansi dan induktasi diantara port 2 dan port 3 , tidak dirasa signifikan seperti penambahan resistor 
ISSN : 2085-3688; e-ISSN : 2460-0997

Modifikasi Pembagi Daya Wilkinson Dual Band pada Frekuensi L-Band dan S-Band

100 ohm diantara port 2 dan port 3, ditunjukkan pada Gambar 11 dan Gambar 12. Sehingga dari model yang diusulkan, komponen isolasi dapat dikurangi dengan hanya menggunakan komponen resistor 100 ohm.

Dari gambar yang ditampilkan pada bagian appendix, dengan memperhatikan perubahan nilai resistor dari $0 \mathrm{ohm}, 10 \mathrm{ohm}, 20 \mathrm{ohm}$ sampai dengan $150 \mathrm{ohm}$, terjadi perubahan signifikan pada parameter S S22, S32, S32 dan S33 dapat diturunkan dari -10 dB sampai dengan $-50 \mathrm{~dB}$. Namun pada parameter $\mathrm{S}$ yang sama, dengan ditambahkan induktansi dan kapasitansi, tidak ada perubahan yang signifikan, hanya dari $-6 \mathrm{~dB}$ sampai dengan $-16 \mathrm{~dB}$.

\section{PENUTUP}

\section{A. Kesimpulan}

Dari model pembagi daya Wilkinson Dual Band Wilkinson, dilakukan perubahan dari sisi frekuensi mencakup frekuensi L-Band pada frekuensi $1,27 \mathrm{GHz}$ dan frekuensi S-Band pada frekuensi 2,3 GHz. Serta pada komponen isolasi dengan hanya menggunakan resistor $100 \mathrm{ohm}$ tanpa menggunakan komponen induktor dan kapasistor. Dari desain, didapatkan hasil dengan bandwidth $\mathrm{S} 11$ di bawah $-10 \mathrm{~dB}$ sebesar 3.6355 GHz, lebih kecil dari bandwidth tanpa komponen isolasi baik $\mathrm{R}$, $\mathrm{L}$ dan $\mathrm{C}$, namun dengan menggunakan resistor $100 \mathrm{ohm}$ sebagai isolasi pada port 2 dan port 3, S23, S32, S22 dan S33 menjadi lebih baik dan dapat dikatakan memenuhi syarat untuk dijadikan pembagi daya ataupun penggabung daya.

\section{B. Saran}

Untuk mengembangkan penelitian lebih lanjut, maka dapat dilakukan beberapa saran berikut:

1. Merealisasikan hasil dari modifikasi yang telah dilakukan

2. Mengembangkan model untuk pita frekuensi yang lebih lebar dengan memanfaatkan sifat dari penyepadan impedansi multi-trafo $\lambda / 4$.

\section{DAFTAR PUSTAKA}

[1] D. Pozar, Microwave Engineering Fourth Edition. John Wiley \& Sons, Inc., 2011.

[2] L. Wu, Z. Sun, H. Yilmaz, and M. Berroth, "A dualfrequency wilkinson power divider," Microw. Theory Tech. IEEE Trans., vol. 54, no. 1, pp. 278-284, 2006.

[3] Y. Wu, Y. Liu, and Q. Xue, "An Analytical Approach for a Novel Coupled-Line Dual-Band Wilkinson Power Divider," IEEE Trans. Microw. Theory Tech., vol. 59, no. 2, pp. 286-294, 2011.

[4] J. Kao, S. Member, and Z. Tsai, "A Modified Wilkinson Power Divider With Isolation Bandwidth Improvement," IEEE Trans. Microw. Theory Tech., vol. 60, no. 9, pp. 2768-2780, 2012.

[5] Y. Lv, D. Shen, W. Ren, J. He, and J. Zeng, "An Equal-Split Wilkinson Power Divider with Tri-Band and Harmonic Suppression," in IEEE International Wireless Symposium (IWS), 2015, pp. 1-4.

[6] ORARI, "Keputusan Nomor KEP-065/OP/KU/2009 tentang Pembagian dan Penggunaan Segmen Band Frekuensi Amatir Radio (Band Plan)," no. 021, pp. 19, 2009.

[7] V. C. Koo, Y. K. Chan, V. Gobi, M. Y. Chua, C. H. Lim, C. S. Lim, C. C. Thum, T. S. Lim, Z. Ahmad, K. a Mahmood, M. H. Shahid, C. Y. Ang, W. Q. Tan, P. N. Tan, K. S. Yee, W. G. Cheaw, H. S. Boey, a L. Choo, and B. C. Sew, "A new unmanned aerial vehicle synthetic aperture radar for environmental monitoring," Prog. Electromagn. Res., vol. 122, no. November 2011, pp. 245-268, 2011.

[8] J. Tetuko and S. Sumantyo, "Development of Circularly Polarized Synthetic Aperture Radar ( CPSAR ) Onboard Small Satellite,” pp. 334-341, 2011.

[9] C. Monzon, "A small dual-frequency transformer in two sections," IEEE Trans. Microw. Theory Tech., vol. 51, no. 4 I, pp. 1157-1161, 2003. 
A. Grafik Pengaruh $R$ terhadap Parameter $S$
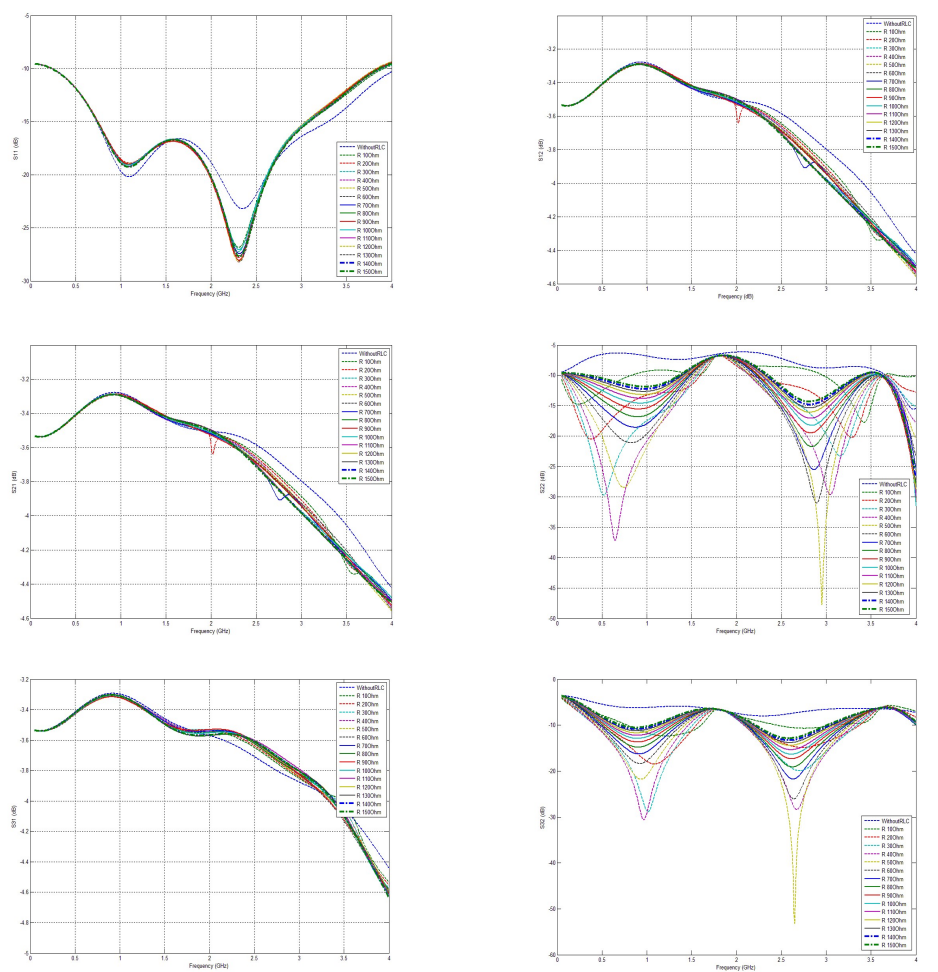
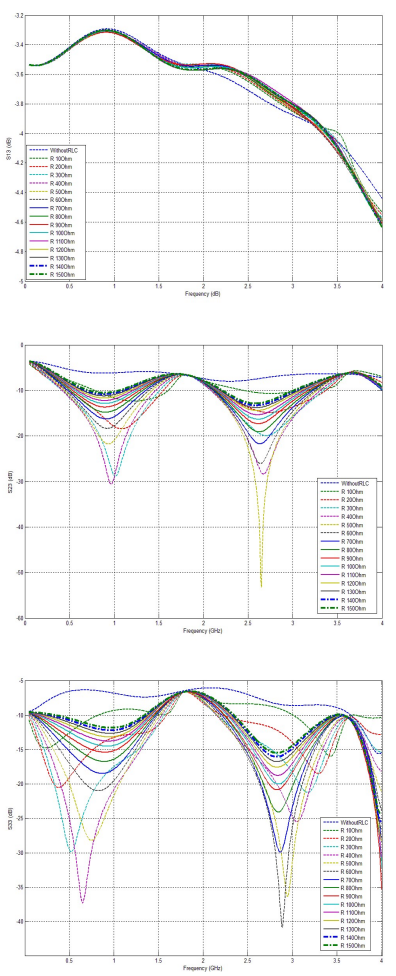

B. Grafik Pengaruh L terhadap Parameter $S$
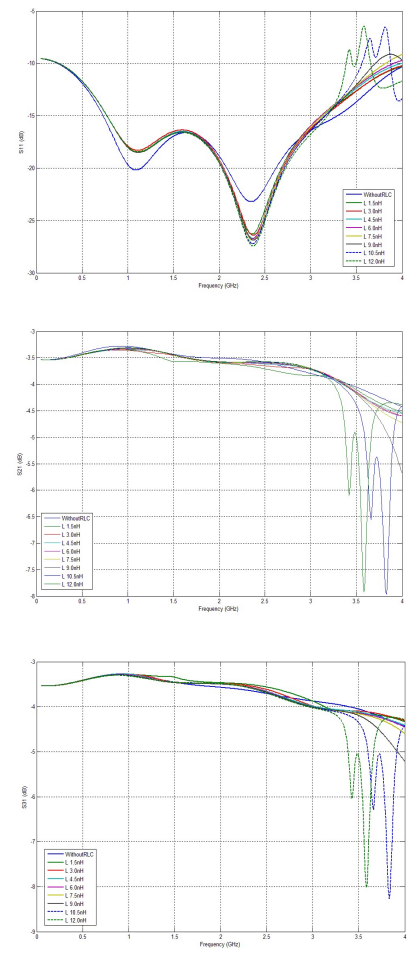
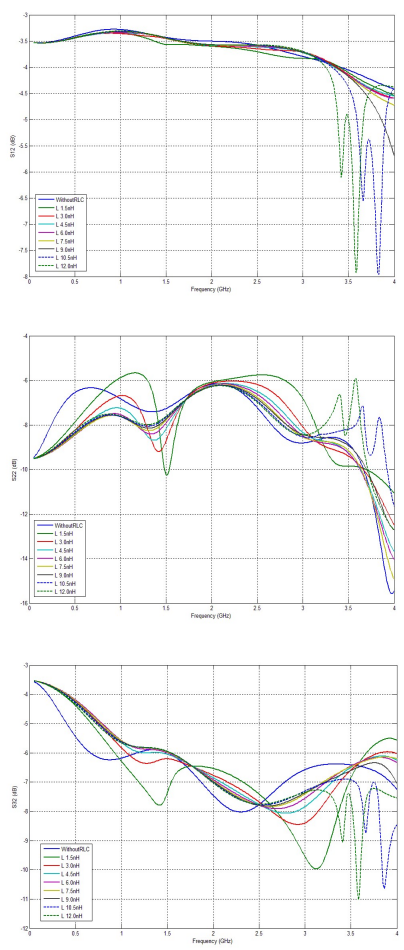
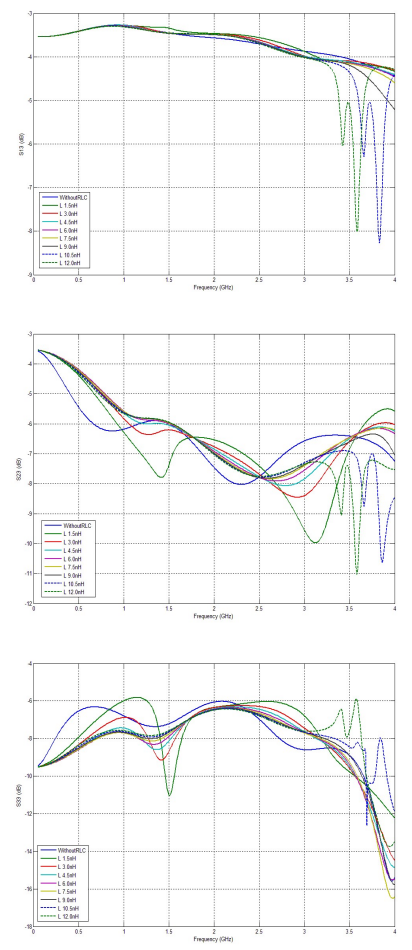
ISSN : 2085-3688; e-ISSN : 2460-0997

Modifikasi Pembagi Daya Wilkinson Dual Band pada Frekuensi L-Band dan S-Band

C. Grafik Pengaruh $C$ terhadap Parameter $S$
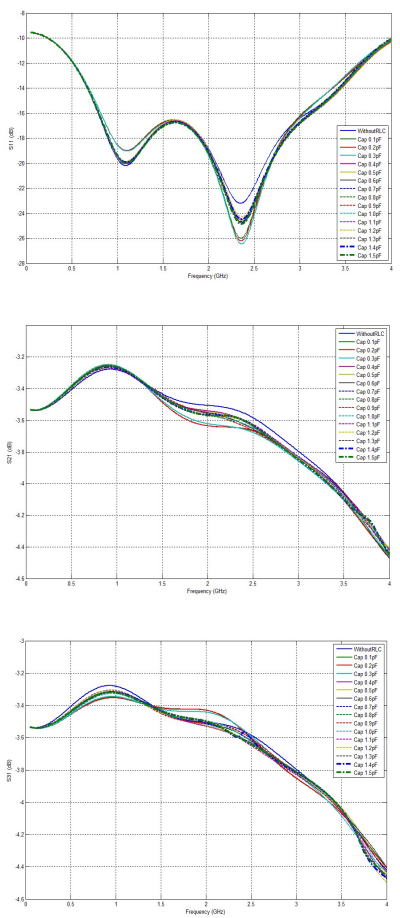
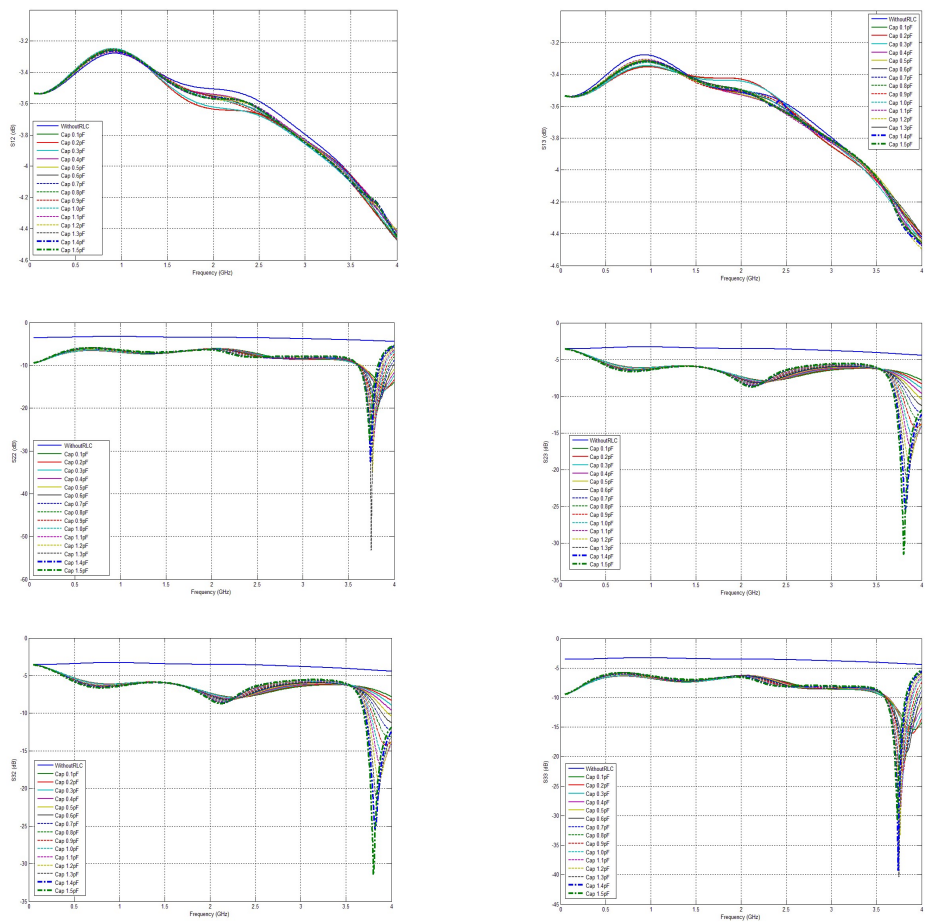